\title{
The South African Pentecostal ostrich of corruption
}

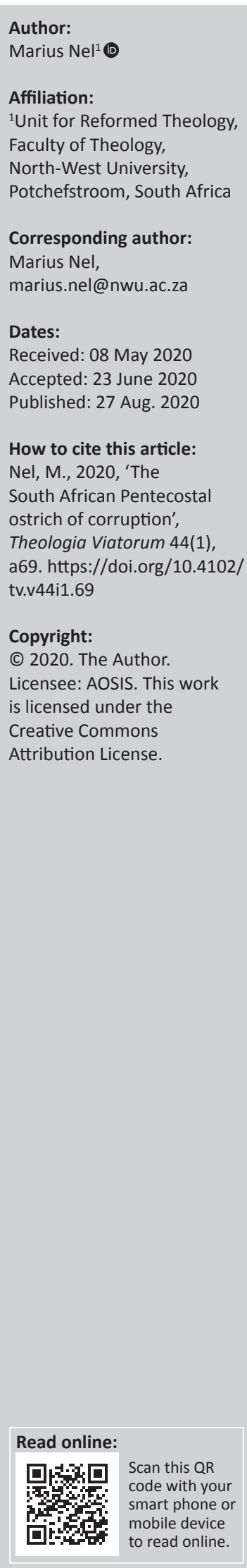

Corruption and corrupt practices in the public and private sector have become endemic to South African society, requiring the cooperation and participation of all citizens to uproot its evils. Classical Pentecostals are historically notoriously absent in confronting societal issues, and they represent as much as a third of the South African population. As a primitivistrestorationist movement, early Pentecostals followed the early Christian church in differentiating themselves from its social, cultural and political Umwelt, acting like the proverbial ostrich that hides its head in the sand to ignore any threat of danger. Why should and how can Pentecostals be involved in confronting corruption? It is argued that Pentecostals should reconsider their widespread lack of involvement in societal issues for historical, hermeneutical and evangelical reasons. By way of a comparative literature analysis, these reasons are discussed, and then, the principles of prophetic politics are developed in broad lines to make some suggestions for their application in South African society.

Keywords: separation; corruption; prophetic politics; community development; Pentecostal; hermeneutics.

\section{Introduction}

The problematics that corruption holds in for South Africa cannot be addressed effectively by a one-dimensional and mono-disciplinary study or by only one agency. The challenge can not only be investigated on the surface but underlying and complicating factors should also be taken into account. Everyone should participate in acknowledging the challenge that corruption holds in for the country, including Christian churches. Pentecostals represent as much as a third of the South African population (see research by Centre for Development and Enterprise 2008). However, classical Pentecostals are notorious for their lack of interest and participation in the development of any community issues. The article investigates reasons for this lack of interest as well as proposes some suggestions on how it can be addressed effectively to ensure that Pentecostals in all walks of life will become involved in, inter alia, the combat of corruption in its many forms. The subject is vital in a country where corruption is threatening the economic survival of the poor because of its negative impact on the state income.

In this study, a specific practical theological methodology is utilised in order to explain, understand and respond to the challenge, whilst a dialogue with other human sciences is kept open (see Kruger \& De Klerk 2016:13). Practical theology is concerned with what moves human beings into action in order to guide them in certain directions. It asks about the given of the situation in order to define what must be done to bring change to the situation. Its descriptive task ends deliberately in a normative task that suggests how the world could and should be in terms of its theological point of departure. Human actions (i.e. faith-praxis or lack of faithpraxis) are considered in light of the extent to which these actions are anchored in and reflect the creative, redemptive and consummating acts of the triune God (Immink 2005:183). The actions are observed in order to design descriptive, interpretive and strategic theories for improving it, and it is done from a theological perspective, connecting human reality with divine reality (Kruger \& De Klerk 2016:16). In other words, it measures human actions according to certain normative criteria found in compliance to God's standard as it is revealed in the Scripture (Wolters 2005:7).

Amos Yong (2014:263) remarks that most Pentecostals in a typical revivalist fashion, with emphasis on simple biblical preaching in a fervent style that would elicit dramatic conversion experiences (Marsden 1991:2), have for the most part neglected developing a theology of culture, that is, a theology of the arts, of politics and of economics. In some cases, they started devising strategies to rectify the situation. In Africa, a slow political awakening started taking place a decade or two ago amongst some Pentecostal groups; in some cases, it was forced on them by the dire political and economic straits that some African countries found themselves in. 
The article describes one aspect of the economic woes, the corruption that marks the politics and economics of some countries. The purpose is to consider strategies for Pentecostals to become involved in combating corruption. Before it can be done, it is necessary to understand their historical non-involvement. The research then looks at different reasons for this lack of involvement before their involvement is motivated in terms of historical, hermeneutical and ecumenical reasons, including the combat of corruption by political and economic leaders. Lastly, some practical pointers will be developed as suggestions for a viable Pentecostal praxis of involvement in societies.

The central theoretical argument is that classical Pentecostals need to rethink their restorationist urge in order to become effective and proactive resisters when confronted with corruption, in light of the urgency of this challenge that threatens South Africa's young democracy, with some civil and public officials as well as national and multinational enterprises and figures engaging in blatant advancement of their own self-interests to the detriment of the taxpayers and the poor.

The argument is deployed in terms of Osmer's (2008:4-12) methodology. The descriptive task consists of describing in short the current situation in South Africa with regard to corruption, asking: What is going on? A second descriptive task is concerned with the Pentecostal restorationist sentiment that led to its apathetic and lethargic non-involvement in societal issues. Next, the interpretative task attempts to explain why the restorationist urge rather necessitates Pentecostals to become involved in prophetic politics by referring to the early church's response to poverty as a defining societal issue. The next task is to formulate some normative principles using theological concepts to interpret the situation and context regarding corruption, utilising a specific Pentecostal hermeneutics that developed in the 1980s amongst Pentecostal scholars, in order to construct ethical norms to answer the question: What ought to be going on? Finally, in the strategic or pragmatic task, some practical pointers will be suggested as strategies for action from normative viewpoints to follow when confronted with corruption in everyday lives and the world, in order to answer the question: How might and should we respond? Normative elements follow on, and it is the result of the experience of a living faith relationship with Jesus Christ as a result of the work of the Holy Spirit in believers. They consequently bear Christ's frame of mind aimed at glorifying the Father and doing God's will (Kruger \& De Klerk 2016:17). These four tasks are not to be performed independently from each other or in a strictly sequential way but should be seen as a cycle.

The aim of the research is to highlight the challenges that corruption holds in for the South African society and discuss the potential impact when Pentecostals get involved in its combat in practical and effective ways. To reach the aim, some objectives need to be met: The current state of research concerning corruption should be described in order to define the challenges that it holds in, the non- involvement of Pentecostals in the societal issues needs to be analysed whilst their involvement in such challenges should be motivated in terms of a prophetic politics and some principles of this type of politics should be highlighted and applied in terms of a few practical pointers.

\section{Descriptive task: Corruption in South Africa}

In 2017, South Africa ranked 71 out of 180 countries that formed part of Transparency International's Corruption Perceptions Index, scoring 43 out of $100 .{ }^{1}$ It followed the footsteps of several other African countries. The 2018 theme for the African Union was fittingly, 'Winning the fight against corruption: A sustainable path to Africa's transformation', illustrating sub-Saharan Africa's reputation as the worst performing region as a whole in terms of corruption. ${ }^{2}$

Corruption is defined for the purpose of this article as the misuse or abuse of a public office or a position of authority for private, material or social gain at the expense of other people (Vorster 2012:1). This includes bribery that is constituted by the use of a reward to pervert the judgment of a person in a position of trust, nepotism, the bestowal of patronage for any inappropriate reason and misappropriation of public resources for private use (Bauer 2000:218). ${ }^{3}$ The Public Service Anti-Corruption Strategy (Department of Public Service and Administration 2002:7-8) explains the dimensions of corruption in terms of bribery, embezzlement, fraud, extortion, abuse of power, conflict of interest, insider trading and abuse of privileged information, favouritism and nepotism and concludes that degrees of intensity vary from the occasional acceptance of bribes to systemic corruption, where bribery has become an accepted way of 'doing business'.

The consequences of corruption include a financial drain on the state, leading to a rise in public expenditure and debt and resultant growing tax burden, capital flight and lower levels of domestic and foreign investment because of a lack of trust in the ruling political party's abilities, a decline in trust from citizens in leadership, growing voter apathy (Bull \& Newell 2003:242-243) and a spirit of despondency (Kruger \& De Klerk 2016:11). The victims who are the most threatened by mismanagement of the state treasury are the poor who

1.https://www transparency.org/country/ZAF: accessed 2018-08-22 By way of comparison. New Zealand is in the first place with 89 , Denmark is in the second comparith, place with 88, whilst Syria, South Sudan and Somalia rank lowest with scores of 14 12 and 9 , rest with an average score 0 66, whilst the worst performing regions are sub-Saharan Africa with an average score of 32 and Eastern Europe and Central Asia with an average score of 34

2.Although there were several countries like Botswana, Seychelles, Cabo Verde, Rwanda and Namibia that showed notable progress in combatting corruption (https://www.transparency.org/news/feature/a_redefining_moment_for_africa accessed 2018-08-22).

3.Max Weber refers to 'patrimonial authority' to describe African postcolonial politics. In patrimonial political systems, the ruler ensures political survival by distributin material benefits to followers. They ruler ensures 'clients' and the public sphere is not material benefits to followers. They become his 'clients' and the public sphere is no clearly distinguished from the private sphere. Today, some political scientists refe to neo-patrimonialism, a hybrid political system in which the 'big man', often president for life, dominates the state apparatus and stands above its laws. administrative system. Officials occupy bureaucratic positions more to acquire personal wealth than to perform public service. The 'big men' use patronage and clientelism in order to remain in power (Theron 2013:2). 
depend on state grants to survive ${ }^{4}$ and (especially) unemployed youth with little prospect of obtaining a job. ${ }^{5}$

Tenderpreneurship has become an accepted corrupt practice that negatively impacts the South African economy because of nepotism prevalent in the government funding of projects directed at improving infrastructure, amongst others (Ulimwengu 2012:1-2). ${ }^{6}$ Corruption has become endemic to the South African society to such an extent that it permeates individual subconsciousness, workplace dynamics, societal norms and socialisation of the maturing youth, who is the lifeblood of the next generation workforce, and it also dictates future economic growth indicators within South Africa (Coetzer \& Snell 2013:30). ${ }^{7}$ The fact is that state corruption is financed by taxpayers, and illegal tax evasion and legal tax avoidance are at times justified as a legitimate response to such misappropriation of state resources. Corruption weakens public service delivery and hinders administrative efficiency, with an accompanying inhibition of growth that is necessary to alleviate poverty and economic inequality. ${ }^{8}$ The estimated costs related to corruption in South Africa, provided in 2013 by Coetzer and Snell (2013:32), include social grant fraud of R1.2 bn per annum, fraud in the land bank totalling R1.1 bn and Fidentia fraud of R1.4 bn, with question marks related to figures linked to fraud within the private sector, the arms trade and price fixing on bread.

The long-term impact of corruption on South African society is wide-ranging. One such list was compiled by Van Vuuren (2009:5) and includes the limitation of service

4.Approximately half (49.2\%) of the adult population were living below the upperbound poverty line (UBPL), according to Stats SA (article posted on 2019-04-04 http://www.statssa.gov.za/? p=12075; accessed 2020-04-30). The number of social grants in South Africa has been increasing exponentially over the years, with an estimated $4 \mathrm{~m}$ in 1994 to $17,443,994$ by October 2017. In recent years, a growing chorus of voices has warned that the numbers are not sustainable in the long term (https://africacheck.org/factsheets/separating-myth-from-reality-a-guide-tosocial-grants-in-south-africa/; accessed 2020-05-04).

5.The unemployment rate for the youth aged between 15 and 24 years is $56.4 \%$. Out of a total of $10.3 \mathrm{~m}$ young people, the number who are not in employment, not in education and not in training is about $3.3 \mathrm{~m}$ (date of article: 2019-07-19; https:// www.fin24.com/Economy/just-in-sa-unemployment-rate-jumps-to-29-the-worstWWW.fin24.com/Economy/just-in-sa-unemplor
since-2008-20190730; accessed 2020-04-30).

6.A related but important field of study concerns itself with differences between rulebased and relationship-based cultures, leading to different perceptions of what is corrupt in Western and African perceptions (Theron 2013). Hooker (2009:252 refers to an example of a Western purchasing agent that is expected to award contracts that are based on the quality of bids whilst comparing available financial information about the bidders. An agent who favours personal friends is viewed as corrupt, because cronyism subverts this transparency-based system. It creates a conflict of interest, with the agent and his or her cronies benefiting at the cost of the company In Africa, however, cronyism is a foundation for trust. A purchasing agent does business with friends because they are trustworthy and they do not ask to see does business with friends because they are trustworthy, and they do not ask to see the company financial statements as this could insult the other's honour. In such system, it benefits the company when the agent reserves business to friends, and cronyism may therefore present no conflict of interest. In a prevalent African view, the basic unit of human existence is the community, and individuals do no distinguish their welfare from the collective welfare. Economy is based on sharing of resources. Incompatibility of this tradition with Western practices and institution accounts for much of the corruption (Hooker 2009:265).

7.Even during the critical period of the 2020 COVID-19 crisis, for instance, the delivery of food parcels to the poor was scarred by various corrupt practices, to the detriment of the needy and destitute (https://www.iol.co.za/capeargus/news/ covid-19-lockdown-politicians-handing-out-food-parcels-is-not-helpingcrisis-46967664; accessed 2020-04-30).

8.South Africa is the world's most unequal society, according to the World Inequality Databases. The top $1 \%$ of South African earners take home almost $20 \%$ of all income generated in the country, whilst the top $10 \%$ take home $65 \%$ of the total income. The remaining $90 \%$ of South African earners get only $35 \%$ of the total income. A study by Stellenbosch University economist Anna Orthofer shows that the wealthiest $10 \%$ own $67 \%$ of all the country's wealth; the remaining $90 \%$ own a the wealthiest $10 \%$ own $67 \%$ of all the country's wealth; the remaining $90 \%$ own a
paltry $7 \%$ of the wealth (date of article: $2019-11019$; https://mg.co.za/article/2019paltry $7 \%$ of the wealth (date of article: 2019-11019; https://mg.co.za/article/2 delivery, the deepening of corrupt elite networks, delayed economic development and consequent growth in unemployment, the destabilisation of the liberal democracy and institutions, the undermining of constitutional rights, a higher crime rate and the development of a crime culture and political corruption that seemingly has become an accepted practice within some political parties.

\section{Descriptive task: Non-involvement of Pentecostals in societal issues}

The early Pentecostal movement justified its origin and existence as a primitivist-restorationist movement ${ }^{9}$ of the Spirit that attempted to re-establish the early, pre-Constantine church in the last days before the second coming of Christ (Anderson 1979:195-222; Marsden 1991:62). ${ }^{10}$ The leaders and members of the early Pentecostal movement came from the revivalist tradition of the Evangelical Awakenings, specifically the Wesleyan-Methodist movement, the holiness movement and the healing movement (Dayton 1987:35-51; Synan 1997:86). They represented the dispensationalist tradition with its separatist tendency, teaching the apostasy of the major churches of 'Christendom' as part of a steady degeneration during the present 'church age' (Marsden 1991:67). In time, early Pentecostals followed the fundamentalist perspective that views believers as outsiders to the power centres of society, its politics and its cultural life. They posed themselves against all worldly powers and did not participate in economic or political life in leading capacity. Like some fundamentalists, they warned of the destruction of the world that was to come and that could be seen in the growing strength of demonic forces (Marsden 1991:110). These movements utilised the same primitivistic matrix defined by the supposition that it is possible and necessary for contemporary believers to deliberately replicate the ethics and values of the early church in a present-day context, with a distinct emphasis on holiness defined in terms of separateness from anything associated with the 'world' (Dayton 1987:40-41). What they shared was the same goal and passion for holiness in order to differentiate themselves from the norms and standards associated with the surrounding 'sinful, fallen' world. ${ }^{11}$ Their inspiration was what they perceived the pre-Constantinian or preChristendom church would have valued highly, that is, holy living and faithful witnessing borne by the power of the Spirit (Bruner 1970:35; Hart 1978:12-13; Nichol 1966:19).

9.The Pentecostal movement started in the Bible schools of Charles Parham and the Azusa Street Revival of William Seymour. 'Primitivistic' is used in the sense of belief in the superiority of an ancient, simple way of living idealised as the norm, belief in the superiority of an ancient, simple way of living idealised as the norm,
here referring to the way of living exhibited by the early pre-Constantine Church here referring to the way of living exhibited by the early pre-Constantine Church
(http://www.merriam-webster.com/dictionary/primitivism; accessed 2019-11-24). (http://www.merriam-webster.com/dictionary/primitivism; accessed 2019-11-24). made impossible by a lack of sufficient information of what the essence of the early church was.

10. Robert Anderson provides an extensive description of the background and motivation.

11.'Holiness' is defined in terms of the Hebrew qdš, referring to being pure and consecrated or dedicated to temple's service in terms of objects and temple servants and to bring oneself into accord with the holy God in an ethical sense (Müller 1997:3:1104-1105, 1116) and the Greek hagios referring to superior moral qualities and possessing certain essentially divine qualities in contrast with what is human (Louw \& Nida 1988:1:745). The implication is that being holy implies that the believer lives relatively differentiated from the surrounding world in religious community. 
They argued that Christians in the early church lived moral lives that attracted interested persons and witnessed to their faith with conviction because they believed that the Spirit of God had been poured out upon the community (Kreider 2005:59-67, especially 62; Nock 1933:188). ${ }^{12}$ In times of persecution, they provided a sense of security, and to the poor, they provided material and spiritual care. Believers knew that care would be taken of them in all circumstances during this life and also after life; the faith community would never leave them wholly to their own resources (Nock 1933:242). The faith community took over the function of the extended family; in many cases, believers were disowned by their family when they turned to the Christian faith. In contrast, in the 'Christendom'13 era, since the fourth century $\mathrm{CE}$, all citizens were compelled to be members of the church and believers participated in all functions of the state and society. Membership of the church became compulsory and worship was institutionalised by the cooperation between ecclesial and political powers (Zimmerman 2012:90).

In their primitivistic urge, most of the early Pentecostal groups did not want to establish 'churches' but they rather designated themselves as a part of a 'mission' or 'movement' that was qualified by its relation to being in the 'apostolic' tradition, with the apostles serving as the eye-witnesses to Jesus' ministry and teaching. ${ }^{14}$ They deliberately associated themselves with the tradition of the apostles and their experience of the baptism with the Spirit and power that characterised their ministry (Asamoah-Gyadu 2013:4; Lake 1994:29). ${ }^{15}$ And their eschatological fervour also did not allow time to institutionalise the movement or require theological training from members who viewed themselves as called to take the good news of Jesus' sacrifice on the cross and the Spirit's empowerment on the day of Pentecost to the ends of the earth.

They also shared a concept of 'holiness' with the movements that preceded them, including the second awakening, holiness and divine healing movements, whereby Christians were expected to separate themselves from any association with the 'world' of sin and fallenness. Participation in politics was especially singled out as a dangerous enterprise that could endanger believers' faith because it would take their eyes from their primary function, which consisted of preaching and teaching on repentance from sin (Tfwala 2016:35). Their

12.In this way, Christians obeyed the injunction found in 1 Peter $3: 15-17$ that states that one should always be ready to make a defense to anyone who demands from you an accounting for the hope that is in you. A.D. Nock in his classic work emphasises that the early church acted from the basic conviction of their being Spirit-filled.

13.'Christendom' is here used in the sense that Hauerwas $(1991: 18,39)$ utilises the terms to refer to the fourth-century church that yielded before the temptation of Constantinian power in order to use that power to further the kingdom of God.

14.The earliest example of this trend was the group that initiated and established the Azusa revival in Los Angeles in 1906, which referred to itself as the Apostolic Faith Gospel Movement (Synan 1997:98). When John G. Lake and Thomas Hezmalhalch's missionary work led to the establishment of the first Pentecostal church in South Africa in 1908, they called it by the same name, the Apostolic Faith Mission of South Africa (Burger \& Nel 2008:64; Chandomba 2007:19; Seymour \& Crawford 1906:1).

15.For example, John G. Lake (1994:183-184) in a sermon entitled, The Habitation of God, stated that the purpose of the gospel was that through Christ, God's son God, stated that the purpose of the gospel was that through Christ, God's son would have many sons begotten of God, in order that Go may be all in all. A new the the early church and resulted in the church being a demonstration of God's powe to change people and the Pentecostal revival of the early twentieth century was in his view a continuation of the same phenomenon. primary focus was on evangelism, preaching a fourfold or fivefold 'Full Gospel' including salvation, sanctification, healing, Spirit baptism and the imminent return of Christ to judge the world (Anderson 2007:9).

With the early church as their role model, they taught that as the early church differentiated itself from its social, cultural and political environment with a view to live a holy life, they aspired to be 'in the world but not of the world'. They became an alternative social mode and expression of power, an alternative to the ways the 'Roman Empire', that is, politics, existed and functioned.

There is no room to argue the case to what extent Pentecostals were successful in imitating the early church or whether it is possible at all to do so. What is relevant for the discussion is the effects of their restorationist and primitivist urge, one of which was that they separated themselves from the social, cultural and political polis in order to live 'sanctified' lives by withdrawing from involvement in the important issues that define contemporary South Africa, including corruption, state plundering, nepotism, abuse of power, embezzlement and various forms of misappropriation, influence-peddling, prevarication, insider trading and abuse of the public purse (see Olivier de Sardan 1999:25-52, especially 27).

What is true is that the early Christians' lifestyle included charity and compassion that went further than mere philanthropy when they devised strategies to enable the poor and needy in their midst to survive. The proof of their message was in the form of transformed lives dedicated to non-violence and forgiveness. They were willing to die for something that was worth living for (Dodds 1965:132) and accepted all people without making gender, race, age or class distinctions. Their distinctiveness and lifestyle of differentiation caused many in the Roman Empire to hate and persecute them but they also won the respect of others (Sanders 2002:372), and it was probably their most effective way of demonstrating the message that they spread. ${ }^{16}$ When Pentecostals argued that it also implied that the early church did not involve itself in politics or economics but concentrated on their missiological task to reach the world with the gospel, it ignored the fact that the early church was powerless in terms of the Roman Empire, representing a Jewish sect without any influence or the necessary numbers to convince the state to listen to it.

\section{Interpretative task: Why Pentecostals should become involved in prophetic politics}

It is argued that Pentecostals should get involved in and even take co-responsibility for societal issues for at least three

\footnotetext{
16.Not all Christians remained faithful during periods of persecution, leading to the divisive issue in the third century of how those should be treated who lapsed from the faith during persections. Should they be rebaptised when they repent of their lapse and should implicated priests be allowed to serve the sacraments gain? During the persecution compire to comply with the law to offer sacrifice in order to recelve a certificate of compliance. The overworked officials in charge of the sacrifices had to turn crowds away, telling them to come another day (Duffy 2015:19-20).
} 
reasons. The first reason has to do with their historical restorationist urge that realised in ways that did not reflect the practice of the early church (as argued above). A second reason has to do with Pentecostals' unique hermeneutical angle, where the direction in the interpretation of the biblical text is from the current situation as defined by the work of the Spirit in their midst, to the text and back. A third reason has to do with the distinctiveness of a unique magisterium, in the four- or fivefold 'Full Gospel' that defines Pentecostalism.

In their restorationist urge, Pentecostals should be involved in the combat of corruption in its many shapes if it wants to do justice to the early church as a role model. Most of the first followers of the 'Way of Jesus Christ' were disenfranchised and marginalised (Archer 2009:161). When confronted with poverty in their midst, the early church, even though it operated without any acknowledgement from state institutions and was powerless as a change agent in itself, involved itself with addressing the problem in various imaginative ways. In the agape feasts, for instance, members of a congregation shared their resource in a daily meal together where those without food were also fed, as a prelude to the communion meal. In the same vein, Acts 2:44-45 explains that believers had all things in common, and when any have need, they would sell their possessions and goods and distribute the proceeds to all. Acts 2:47 ascribes the goodwill of the general populace and the growth and extension of the early church directly to their involvement in societal issues. In a treatise by Justin Martyr (100-165 CE), addressed to Antoninus Pius and his associates with the intention of proving the unreasonableness of persecution, the church father describes the change produced in the lives of Christians. Whilst they formerly rejoiced in the uncleanness of a morally corrupt life, they now live in chastity. They used magic arts and loved money and possessions more than anything else but now they live their lives dedicated to God. They share what they have and give to everyone who is in need. Formerly, they hated and killed one another and would not eat with people of another race. But now, because of the manifestation of Christ in their lives, they have a common life together and pray for their enemies and try to win over those who hate them without any cause (Nock 1933:215). Justin Marty in his anthology of precepts from the Gospels also emphasises sexual purity, compassion and generosity, mercy towards others and freedom of thought for the morrow, refusing to bear ill towards anyone and helping all without anger, avoiding oaths and telling the truth and reverencing God and God only as the marks of the Christian church (Nock 1933:215). The emphasis on sharing in generosity with other people is clear.

When it comes to a differentiated lifestyle, the most important markers of the early church seemed to be the compassion that existed between believers and unbelievers, and the early believers' unwillingness to participate in anything that might compromise their high ethical and moral standards. Hence, Pentecostals did not embody the alternative social example that the early church set. Their preoccupation with their own community, at the cost of cooperation with other Christians and denominations, did not represent the leadership style of Jesus as suffering servant, and their lack of involvement with social issues that determined the welfare of groups of people indicates that they did not represent the distinct lifestyle of early Christians. They were so heavenly minded that they were earthly no good (Piper 2014). It must be admitted that this is changing, ${ }^{17}$ especially amongst Africa's neo-Pentecostal groups, illustrating the wide diversity represented by global Pentecostalism. ${ }^{18}$

At first, Pentecostalism was not institutionalised and did not develop any organisation that is essential for any organisation to exist in the society, in an attempt to free itself from the formalised institutionalism that marked the established mainline churches, as argued above. They did not have a professional pastorate but, as a realisation of their emphasis on the priesthood and prophethood of each believer, left room for democratic participation in all activities, in terms of the individual charismata that all believers had received. Without any larger organisation that could have corporately become involved in societal issues, individual members focused on reaching as many people as possible with the gospel message before the imminent return of Christ, as they expected, would interrupt their mission's work. They did not find time to participate in politics or other societal matters. In time, when Pentecostalism could not resist the process of institutionalism and routinisation, their nearly exclusive emphasis on the faith community and its extension by way of evangelism disqualified them from wider interests.

A second reason why Pentecostals should reconsider their lack of involvement in societal issues, and especially what may constitute the 'politically incorrect' and unpopular combat of corruption, is in their hermeneutical angle that differs from other traditions. Instead of reading the Bible and applying its interpretation on the current situation as far as possible, Pentecostals read the Bible from their encounters with the Spirit and the revelation of the Spirit in their lives, and they apply their interpretation only if they perceive that it represents the product of their illumination by the Spirit. In living in a society where corruption has seemingly permeated and soaked almost every sector of society, the biblical message of the integrity of Jesus and his disciples will motivate them to pursue political and economic changes, for the sake of the deprived and impoverished. These people are the biggest losers in the corruption game because South Africa's unequal economic structures cannot be addressed properly if state income is getting lost because of the corrupt practices of illegitimately awarded tenders and theft. Pentecostals will also hold political leaders responsible for

17.One example will need to suffice. On 19 November 1999, the office bearers of the AFM of SA read a testimony before the Truth and Reconciliation Commission where they confessed the errors of the white Apostolic Faith Mission of South Africa's (AFM's) ways before 1994 when white believers became 'increasingly besotted by political and racial ideology, placing impediments on multiracial worship', renting asunder the church into four race-based churches (Burger \& Nel 2008:440-441).

18.A Pew survey clearly demonstrates that some Pentecostals are not apolitical anymore. With the growth that characterises the movement, it implies that its effects on the political terrain will become more and more pronounced effects on the political terrain will become more and more pronounced
(https://www.washingtontimes.com/news/2007/jan/21/20070121-0958404117r/; accessed 2018-08-21). 
the trust endowed to them by the electorate and organise events when the trust is violated to raise public awareness.

A last reason why Pentecostals should become involved in an issue such as corruption is because of their 'Full Gospel' message of Jesus as saviour, sanctifier, Spirit baptiser, healer and coming King. In their evangelical zeal to proclaim the gospel, they cannot help but get involved in an issue such as corruption that inherently causes the fruit of the young South African democracy to rot. If they aspire to establish a society with Jesus as king, their expectations of the moral standards of political and economic leaders will require them to engage with issues that harm and threaten people's livelihood.

\section{Normative task: Some principles of prophetic politics}

It is suggested that what Pentecostals need is the development of principles in the service of a prophetic politics that is informed by their spirituality and piety, which engages the public sphere boldly. It is precisely, as the church embodies, the ecclesial way of Jesus that it provides a prophetic alternative to the world's conventions of corruption, patronage and oligarchy (Yong 2010:250). Africa's hierarchical patronage system ensures that each level is subservient to their benefactors at the higher level, so that corruption, bribery and favouritism are the rule rather than the exception, as was the case in the time when Jesus lived.

An engagement with prophetic politics will result in Pentecostal communities purposefully engaging the broader political realities and providing forms of socio-political and economic solidarity with people who are the victims of corruption and the effects of whistle-blowing on corrupt practices that went wrong. In the process, Pentecostals will be exposed to a biblical ethics where the Spirit highlights its consequences for daily living, influencing citizens as well as members employed by state agencies in terms of sensitivity for corrupt practices. Christ will then be their model of human conduct and attitude, and they would enhance the deeper meaning of honesty, fairness, responsibility, compassion, love and accountability (Vorster 2012:145).

In traditional Africa, the community played a significant role. Communal effort in daily tasks of life was taken for granted. Hence, care of the elderly and frail and physically and mentally challenged were taken care of by the community. Whilst Western people worked mostly in selfish ways for their care and enrichment, in Africa one worked in order to care for the larger family unit that consisted of all the members of the extended family. Children took the responsibility for taking care of their elderly parents. It is suggested that Pentecostals should reconnect to this value system by subordinating the believer's self to solidarity with the community, including the larger community in which they live. Instead of joining in neoliberal capitalism's urge for personal enrichment and competition, they should bear one another's burdens. Their profits should be considered not as a provision only for their own family's needs and old age but instead utilised in communal sharing, achievements and investments (Yong 2010:313).

According to Yong (2010:239-242), a Pentecostal prophetic politics also recognises and announces that allegiances to the state are secondary to allegiances to God and challenges the state to do what it is supposed to do, to uphold the law and encourage Spirit-filled believers to explicitly witness in the public square, even and specifically in the 'naked public square', characterised by the absence of religion from both the political and civic arena (Yong 2010:248). Believers should deliberately not separate themselves from the world but live within the world as a counter-testimony to the watereddown moral values and standards of their societies.

Their hermeneutical angle, as argued above, propels Pentecostals to read their current situation, in terms of their encounter with Jesus through his Spirit, into the equation that comprises the interpretation of Scripture. A prominent societal issue such as corruption cannot be ignored by them because the Bible is concerned with the actions of people, such as corruption, that impair other people.

\section{Strategic task: Practical pointers for Pentecostals when confronted with corruption}

Applying these principles requires that Pentecostals involve themselves with societal issues, necessitating them to partake in institutions that write and implement policies as far as possible. Their involvement may not only be limited to observing and commenting on worrying trends but requires them to take the lead where possible and necessary. It is true that previously Pentecostal participation in politics at times yielded some bad fruit. ${ }^{19}$ Prophetic politics in Africa has in recent times actualised more successfully in Pentecostal participation in politics. Pentecostals, for instance, were involved in the establishment of several political parties in African states, and Zambia has had two Pentecostal presidents (Anderson \& Pillay 1997:238). ${ }^{20}$ These Pentecostals established close alliances with certain political leaders, creating the danger of compromising their ethos (Burgess 2012:31). Such involvement also developed

\footnotetext{
19.One such example is the case of Gerrie Wessels, elected vice-president of the AFM in April 1943 when he was 30 years old, after successfully initiating organised in April 1943 when he welfare work whth women or alleviating welfare needs in their local communities. The ruling National Party asked him to stand for the Senate in 1955 and he was elected as a senator in that same year. He managed to get a measure of recognition and acceptance for the AFM in the 'higher circles' of society. His involvement in government politics eventually led to a schism in the AFM in 1958, with many members dissatisfied with his prominence in advocating apartheid policies to the benefit of the ruling party (Burger \& Nel 2008:130-131). Before 1948, the ruling government political party - the United Party - had many supporters in the AFM (Burger \& Nel 2008:152), partly explaining the reaction by some to Wessels' political participation.

20.President Fredrick Chiluba who controversially declared Zambia a Christian nation in 1991 and President Edgar Lungu who called the nation to prayer, fasting and reconciliation and proclaimed a 'National Day of Prayer and Fasting Service' in 2015 (http://www.times.co.zm/?p=66547; https://eliasmunshya.org/2015/10/15/afterwe-have-said-amen-towards-a-Pentecostal-theology-of-politics-in-zambia/ accessed 2018-07-19). A recurring problem is when Christian believers using Christian platform to get elected in political positions do anything morally wrong that the press could use against them, which then casts shadows on their confession of belief.
} 
over time in South Africa. Frahm-Arp (2018), for instance, discusses several examples of South African megachurches that initially did not participate in politics but in the end became involved. For instance, Jacob Zuma as president of the African National Congress (ANC) invited Ray McCauley of Rhema Bible Church to head the National Interfaith Leadership Council (NILC), and before the 2009 elections McCauley invited Zuma to Rhema to 'preach' to his congregation (Frahm-Arp 2018:1). Grace Bible Church invited political officials from different affiliations to address their congregations in the build-up to the 2014 elections. They motivated it by stating that the congregation should be informed about political choices in order to elect Christians into key political positions (Frahm-Arp 2018:5).

Other ways of prophetic politics successfully employed by Pentecostals include their involvement in schools to sharpen students' moral ability, raising public awareness on the dire problem of corruption and its effects on the South African society, influencing personal morality, nurturing civic responsibility, raising ethical awareness (Vorster 2012:145) and advocating for peace and justice (Yong 2010:248). Kruger and De Klerk (2016:290) emphasised that the whole community should develop awareness to the extent of corruption. Churches can use their prophetic calling through teaching and preaching to enhance the alertness that corruption is wrong and that greed, nepotism, favouritism and careerism represent behaviour that is socially destructive and morally indefensible.

The South African Constitution (Section 195) cites certain basic values and principles to regulate public administration. The most important of these values and principles are as follows: A high standard of professional ethics must be promoted and maintained; efficient, economic and effective use of resources must be promoted; public administration must be held accountable; and it must be broadly representative of the South African people, with staff management practices based on ability, objectivity and fairness (see Theron \& Lotter 2012:97). ${ }^{21}$ It is proposed that Pentecostals use these basic values and principles to evaluate and engage the public sector (as well as the private sector) and hold it accountable. The government's strategy calls on civil society to play an active role in holding the public sector accountable for its ethical practices and allows for their integral participation. Pentecostal churches should follow such routes to gain the necessary knowledge to enable their members to become involved in the prevention of corruption. According to Vorster (2012:141), churches are ideally placed to act as moral 'opinion makers' in communities because they exist and are involved at the grassroots level of society.

Many Pentecostals are also employed in the public sector and they need to be activated and empowered to impact and 21.http://info.gov.za/documents/constitution/1996/a108-96.pdf; accessed 2018-08-30 influence their workplace for good. ${ }^{22}$ What should believers' responsibility be towards their employers in terms of corruption that has become endemic to the South African society and the public sector? ${ }^{23}$ With many public servants attending its worship services, the church should promote a culture of whistle-blowing amongst them, and they should be encouraged as believers to courageously report any wrongdoing that they are witness to. Where necessary, the church should act as a 'watchdog' (Vorster 2012:140) and engage State organs to highlight existing risks and problems of whistle-blowing in order to improve the system, serving as a stakeholder to establish professional ethical standards. The culture of silence must be tackled at grassroots level (Theron \& Lotter 2012:109) by Christians who act as salt and light in society (Mt 5:13-16), by fighting corruption and moral decay that jeopardise justice and righteousness (Theron \& Lotter 2008:301). Christians should be equipped to confront corruption, by clearly distinguishing the ethical issues at stake, identifying the possible personal consequences if they should blow the whistle and consider any alternatives available to alleviate the risk and suggesting alternative ethical actions instead of questionable ones (Arbogast 2008:23).

On a personal level, the church should also encourage believers to beware of the temptations of personal enrichment by acting in corrupt ways (Gal 6:1; 1 Cor 10:12), whilst at the same time faithfully living out their testimonies as being children of God through grace. ${ }^{24}$ A significant element of a godly life is a new set of ethical values accompanied by the renewal of the mind ( $\operatorname{Rm~12:2;~Eph~4:23;~Keener~2016:32).~}$ Social behaviour is determined for Christians by the golden rule, to do to others as they would have them do to them (Mt $7: 12)$; that should serve as the guide for daily life and contact with others (France 1985:149). The golden rule summarises Jesus' teaching in the Sermon on the Mount (as well as the Law and Prophets) by radically gearing believers to the well-being of the neighbour, including the enemy, calling for

22. South Africa has an inordinate and unaffordable number of employees in the public sector. Africa Check reports on 16 October 2014 that according to its June 2014 Quarterly Employment Statistics (QES) survey, South Africa had 4,55,701 national government employees, a further $11,18,748$ people worked for provincial authorities, 3,11,361 people were employed by local authorities and 2,75,851 employees worked for 'other government institutions' like libraries, parks, zoos and education and training authorities. This adds up to a grand total of $2161 \mathrm{~m}$ civil servants. Between 2005 and 2012, the number of South African government employees increased by more than a quarter, leading to concerns about long-term sustainability. Government spending on salaries was combined with widespread corrupt practices within the public service to threaten South Africa's sustainability corrupt practices within the public service to threaten South Africa's sustainability (Van der Walt \& Theron 2014:3). By 2018, $2.7 \mathrm{~m}$ people worked in the public sector. They earned an average wage of R338,000 annually or R28,000 per month, number that, according to the Mid Term Budget Speech of 2017, is R9000 highe than the average wage of non-agricultural workers (https://www.thesouthafrican om/public-servants-pay-south-africa/; accessed 2018-09-05), with 35\% of South Africa's R1.67 trillion budget used to pay their salaries.

23.The public sector is regulated by the Public Service Anti-corruption Strategy, formulated in 2002 (see https://www.gov.za/zu/AntiCorruption; accessed 2020-04-29, Webb 2010). The strategy prescribes training and education of civil servants in ethical awareness and guidelines of conduct. Its aim is to improve management policies and practices to ensure honest business and appropriate mechanisms to coordinate and integrate anti-corruption work, providing improved access to report wrongdoing and protection of whistle-blowers and witnesses and allowing for the increase in the institutional capacity of the courts and numerous watchdog agencies such as the National Anti-Corruption Campaign and partnerships with the Business and Civil National Anti-Corruption Campaign and partnerships with the Business and Civi Society Sectors to curb corrupting practices (http://unpan1.un.org/
public/documents/CPSI/UNPAN025768.pdf; accessed 2018-09-03).

24.The culture created by the message of prosperity preached by some neoPentecostal groups may contribute to unbridled consumerism, with members encouraged to yearn for a better life and expensive high-tech gadgets, etc., leading, in many cases, to unfulfilled dreams and shattered hopes (Nel 2020). 
behaviour that is not focused on the self but on the other person (Nolland 2005:330). It exposes greed and selfishness and promotes integrity and personal honesty in the lives of Christians who are satisfied with their material position, because 1 Timothy 6:6 teaches them that true godliness with contentment is itself great wealth. They purposefully and deliberately avoid the temptation of greed.

A related problem is the mediocre salaries paid to some officials, which increases the possibility that they might be enticed into corrupt acts to provide for themselves by taking bribes or misusing funds, especially if the system has been shown to be corruptible by numerous others. It has been shown in research that corruption is much higher and more destructive in poor developing societies. Such corruption is then justified as 'self-remuneration'. Pentecostals should strive for fair and sufficient salaries for officials to live a decent life and a caring economy that addresses the plight of the poor (Vorster 2012:144).

What South Africa needs is a holistic and integrated approach to fighting corruption, with a balanced mixture of prevention, investigation, prosecution and public participation as the platform for the strategy. The State should be encouraged by the church and its leaders to treat corruption as the criminal acts they are and to act against its perpetrators according to the Prevention and Combating of Corrupt Activities Act 12 of 2004 (Act 12, 2004). ${ }^{25}$ It seems that a part of the problem is that the country's highly regarded laws circumventing corruption are not necessarily applied effectively by the different law enforcements agencies. ${ }^{26}$ The church should engage where necessary with the necessary institutions that have anticorruption functions, such as the National Prosecuting Authority (specifically the Directorate of Special Operations and Asset Forfeiture Unit), the Public Protector, the Auditor General, the Public Service Commission, the Special Investigation Unit (SIU), the South African Police Service (the Commercial Branch and the SAPS Anticorruption Unit), the National Intelligence Agency, the Independent Complaints Directorate and the South African Revenue Services (Public Service Anti-corruption Strategy 2002:14).

Lastly, South African legislation is sufficient in increasing access to information, also with regard to corruption, as contained in inter alia, the Promotion of Access to Information Act 2000 (Act 2 of 2000), the Protected Disclosures Act 2000 (Act 26 of 2000) and the Administrative Justice Act 2000 (Act 3 of 2000), although the Protection of State Information Bill, 2011 undermines the accessibility of some of the relevant information. ${ }^{27}$ It is proposed that Pentecostals should create agencies that actively access information about corrupt practices in cooperation with organisations with the same goal (see Chetty \& Pillay 2017; Hlongwane 2018) and engage

25.http://www.justice.gov.za/legislation/acts/2004-012.pdf; accessed 2018-09-03.

26.Vorster (2011:34) refers to the research of Treisman (The Causes of Corruption: A Cross-National Study, 2000) and remarks that factors present in the South African society cause the legal culture not to be so robust as might be expected and the religious monitoring not as uncompromising as it should be.

27.https://pmg.org.za/bill/278/; accessed 2018-08-30. the government and other state agencies to confront it openly in a transparent manner.

\section{Conclusion}

By way of conclusion, Pentecostalism in its primitivistrestorationist urge to follow the early church as its model separated and differentiated itself from its social, cultural and political Umwelt, interpreting the call to holiness in terms of withdrawal from society as far as possible. They acted like the proverbial ostrich that hides its head in the sand to ignore any threat of danger. It is argued that Pentecostals should reconsider their involvement in societal issues, including corruption, for several reasons. The early church, characterised by the powerlessness of their position as a Jewish sect within the Roman Empire, did impact their society effectively by their involvement in society's challenges. Instead of withdrawing itself, Pentecostalism's restorationism serves as a good reason to get involved in societal ills. Another reason is hermeneutical, that Pentecostals in their interpretation of Scripture begin with their experience of God's heart for people through the Spirit and a contemporary South African situation that is determined to a certain extent by corruption that plunders state resources and deters foreign and local investors. In reading the Bible, the Spirit enlightens their moral and ethical awareness and sensitivity and empowers them to become change agents in their societies. They need to be conscientised, which, according to Yong (2006:281), consists of a process of catechism whereby individuals and whole communities come to understand Christian faith not only in individualistic terms but also, as embracing, in a holistic sense, human embodiment within and responsibility for specific social, economic and political situations. A third reason is concerned with Pentecostals' emphasis on a 'Full Gospel' that emphasises Jesus' changing of the hearts of people and their mission to reach the world with the good news. Some principles were developed for a prophetic politics that is informed by Pentecostal spirituality and piety and engages the public sphere boldly and provides counterconventional communities. The product will be in the form of believers who do not withdraw from the world but provide with their lifestyles a counter-testimony to moral values and standards of their societies. Several suggestions were made for the application of prophetic politics in the South African society. Pentecostals' involvement should include observing and commenting on worrying trends and even taking the lead in confronting it where necessary. They should influence personal morality and nurture civic responsibility amongst their members and actively advocate for peace and justice. They should also evaluate the practices of the public sector in terms of the government's own strategies and hold it accountable. Pentecostals employed in the public sector need to be empowered to influence their workplace; a culture of silence must be replaced and whistle-blowers should be recognised, recommended and defended against persecution and discrimination. Believers should be encouraged to guard against personal enrichment through corruption and to be content with what they have. And the church should encourage the State to prosecute corrupt officials and to act decisively against all perpetrators of corruption. 


\section{Acknowledgements Competing interests}

The author declares that no competing interest exists.

\section{Authors' contributions}

The author declares that he is the sole author of this research article.

\section{Ethical consideration}

This article followed all ethical standards for carrying out research without direct contact with human or animal subjects.

\section{Funding information}

This research received no specific grant from any funding agency in the public, commercial or not-for-profit sectors.

\section{Data availability statement}

Data sharing is not applicable to this article as no new data were created or analysed in this study.

\section{Disclaimer}

The views and opinions expressed in this article are those of the authors and do not necessarily reflect the official policy or position of any affiliated agency of the authors.

\section{References}

Anderson, A.H., 2007, 'Spreading fires: The globalization of Pentecostalism in the twentieth century', International Bulletin of Missionary Research 31(1), 8-14. https://doi.org/10.1177/239693930703100102

Anderson, A.H. \& Pillay, G.J., 1997, 'The segregated spirit: The Pentecostals', in R. Elphick \& R. Davenport (eds.), Christianity in South Africa: A political, social, and cultural history, pp. 227-241, University of California Press, Berkeley, CA.

Anderson, R.M., 1979, Vision of the disinherited: The making of American Pentecostalism, Hendrickson, Peabody, MA.

Arbogast, S.V., 2008, Resisting corporate corruption: Lessons in practical ethics from the Enron Wreckage, M\&M Scrivener, Salem, MA.

Archer, K.J., 2009, A Pentecostal hermeneutic: Spirit, scripture and community, CPT, Cleveland, TN.

Asamoah-Gyadu, J.K., 2013, Contemporary Pentecostal Christianity: Interpretations from an African context, Wipf \& Stock, Eugene, OR.

Bauer, C., 2000, 'Public sector corruption and its control in South Africa', in K.R. Hope \& B.C. Chikulo (eds.), Corruption and development in Africa: Lessons from country case-studies, pp. 218-233, Palgrave, New York, NY.

Bruner, F.D., 1970, A theology of the Holy Spirit, Eerdmans, Grand Rapids, MI.

Bull, M.J. \& Newell, J.M., 2003, 'Conclusion: Political corruption in contemporary democracies', in M.J. Bull \& J.M. Newell (eds.), Corruption in contemporary politics, pp. 234-247, Palgrave Macmillan, New York, NY.

Burger, I. \& Nel, M., 2008, The fire falls in Africa: A history of the Apostolic faith mission of South Africa, Christian Art, Vereeniging.

Burgess, R., 2012, 'Pentecostals and political culture in sub-Saharan Africa: Nigeria, Zambia, and Kenya as case studies', in M. Wilkinson (ed.), Global Pentecostal movements: Migration, mission, and public religion, pp. 17-42, Brill, Leiden.

Centre for Development and Enterprise, 2008, Under the radar: Pentecostalism in South Africa and its potential social and economic role, viewed 08 May 2020, from https://issuu.com/cdesouthafrica/docs/under_the_radar_-_Pentecostalism_in.

Chandomba, L., 2007, The history of apostolic faith mission and other Pentecostal missions in South Africa, AuthorHouse, Keynes.

Chetty, J. \& Pillay, P., 2017, 'Independence of anti-corruption practices: A comparative study of South Africa and India', African Journal of Public Affairs 9(8), 105-120.

Coetzer, W. \& Snell, L.E., 2013, 'A practical-theological perspective on corruption: Towards a solution-based approach in practice', Acta Theologica 33(1), 29-53. https://doi.org/10.4314/actat.v33i1.2
Dayton, D.W., 1987, Theological roots of Pentecostalism, Hendrickson, Peabody, MA.

Department of Public Service and Administration, 2002, Public service anti-corruption strategy, viewed 22 August 2018, from http://unpan1.un.org/intradoc/groups/ public/documents/CPSI/UNPAN025768.pdf.

Dodds, E.R., 1965, Pagan and Christian in an age of anxiety, Cambridge University Press, London.

Duffy, E., 2015, Saints and sinners: A history of the Popes, Yale University Press, London.

Frahm-Arp, M., 2018, 'Pentecostalism, politics, and prosperity in South Africa', Religions 9(298), 1-16. https://doi.org/10.3390/rel9100298

France, R.T., 1985, Matthew, IVP Academic, Downers Grove, IL.

Hart, L.D., 1978, 'A critique of American Pentecostal theology', PhD dissertation, Southern Baptist Theological Seminary.

Hauerwas, S., 1991, After Christendom, Abingdon, Nashville, TN.

Hlongwane, P., 2018, 'The anti-corruption institutions in South Africa: A panacea to governance ills?', South African Public Law 33(2), 1-24. https://doi.org/ 10.25159/2522-6800/2949

Immink, F.G., 2005, Faith: A practical theological reconstruction, Eerdmans, Grand Rapids, MI.

Hooker, J., 2009, 'Corruption from a cross-cultural perspective', Cross Cultura Management 16(3), 251-267. https://doi.org/10.1108/13527600910977346

Keener, C.S., 2016, The mind and the spirit: Paul's approach to transformed thinking, Baker Academic, Grand Rapids, MI.

Kreider, A., 2005, 'Beyond Bosch: The early church and the Christendom shift' International Bulletin of Missionary Research 29(2), 59-67. https://doi.org/ $10.1177 / 239693930502900201$

Kruger, F. \& De Klerk, B. (eds.), 2016, Corruption in South Africa's liberal democratic context: Equipping Christian leaders and communities for their role in countering corruption, AOSIS, Durbanville.

Lake, J.G., 1994, John G. Lake: His life, his sermons, his boldness of faith, K. Copeland (ed.), Kenneth Copeland Publications, Fort Worth, TX

Louw, J.P. \& Nida, E.A., 1988, Greek-English Lexicon of the New Testament, United Bible Societies, New York, NY.

Marsden, G.M., 1991, Understanding fundamentalism and evangelicalism, Eerdmans, Grand Rapids, MI.

Müller, H.-P., 1997, 'qdš holiness', in E. Jenni \& C. Westermann (eds.), Theological lexicon of the old Testament, pp. 1103-1118, Hendrickson, Peabody, MA.

Nel, M., 2020, The prosperity gospel in Africa: An African Pentecostal hermeneutical consideration, Wipf \& Stock, Eugene, OR.

Nichol, J.T., 1966, Pentecostalism, Logos, Plainfield.

Nock, A.D., 1933, Conversion, Oxford University Press, Glasgow.

Nolland, J., 2005, The gospel of Matthew, Eerdmans, Grand Rapids, MI.

Olivier de Sardan, J.P., 1999, 'A moral economy of corruption in Africa', Journal of Modern African Studies 37(1), 25-52. https://doi.org/10.1017/S0022278X99002992

Osmer, R.R., 2008, Practical theology: An introduction, Eerdmans, Grand Rapids, MI.

Piper, J., 2014, 'I do not aspire to be a normal guy', Desiring God, viewed 22 August 2018, from https://www.desiringgod.org/articles/i-do-not-aspire-to-be-a-regular-guy.

Sanders, J.T., 2002, 'Establishing social distance between Christians and both Jews and Pagans' in A.J. Blasi, J. Duhaime \& P. Turcotte (eds.), Handbook of early Christianity: A social sciences approach, pp. 361-382, Altamira, New York, NY.

Seymour, W.J. \& Crawford, F.L., 1906, 'Editorial', Apostolic Faith 1(1), 1.

Synan, V., 1997, The Holiness-Pentecostal movement in the United States, 2nd edn. Eerdmans, Grand Rapids, MI.

Tfwala, N.H., 2016, 'Participation of Pentecostal churches in politics: A pastoral perspective', PhD dissertation, University of Pretoria.

Theron, P. \& Lotter, G.A., 2008, "'Do not be yoked together with unbelievers": Challenges for Christians and the church in a post-modern context', Ned Geref Teologiese Tydskrif 49(3\&4), 300-316. https://doi.org/10.4314/actat.v32i1.6

Theron, P. \& Lotter, G.A., 2012, 'Corruption: How should Christians respond', Acto Theologica 32(1), 96-117.

Theron, P.M., 2013, 'Corruption in sub-Saharan Africa: A practical-theological response', In die Skriflig/In Luce Verbi 47(1), Art. \#676, 1-8. https://doi.org/
$10.4102 /$ ids.v47i1.676

Treisman, D. 2000, 'The causes of corruption: A cross-national study', Journal of Public Economics 76(3), 399-457. https://doi.org/10.1016/\$0047-2727(99)00092-4

Ulimwengu, J., 2012, 'The ANC produced the finest people to walk this earth; look at it today and weep', East African Review, viewed 28 August 2018, from http:// www.theeastafrican.co.ke/OpEd/comment/-/434750/1306042/-/4oanwdz/-/.

Van der Walt, I.J. \& Theron, P.M., 2014, 'Suid-Afrika se Volhoubaarheid in die Lig van Wêreldbeelde: Prakties-Teologiese Perspektiewe', Koers - Bulletin for Christian Scholarship 79(1), Art. \#2115, 1-9. https://doi.org/10.4102/koers.v79i1.2115

Van Vuuren, H., 2009, 'A civil society perspective: Introducing anti-corruption in the (South) African context', Paper presented at the Workshop on Promoting
Professional Ethics in the Public Service, at the Centre for Business and Professional Ethics, University of Pretoria, South Africa, 25 November.

Vorster, J.M., 2011, Managing corruption in South Africa: The ethical responsibility of churches, Unpublished work.

Vorster, J.M., 2012, 'Managing corruption in South Africa: The ethical responsibility of the church', Scriptura 109, 133-147. https://doi.org/10.7833/109-0-130

Webb, W.N., 2010, 'The public service anti-corruption strategy: A case study of the Department of Correctional Services', PhD dissertation, University of South Africa. 
Wolters, A.M., 2005, Creation regained: Biblical basics for a reformational worldview, 2nd edn., Eerdmans, Grand Rapids, MI.

Yong, A., 2006, Spirit-word-community: Theological hermeneutics in Trinitarian perspective, Wipf \& Stock, Eugene, OR.

Yong, A., 2010, In the days of Caesar: Pentecostalism and political theology The Cadbury Lectures 2009, Eerdmans, Grand Rapids, MI.
Yong, A., 2014, 'The spirit, the body, and the sacraments: Pentecostal-Catholic dialogue and the "Pneumatological-Sacramental" imagination', in S.D. Moore \& J.M. Henderson (eds.), Renewal history \& theology: Essays in Honor of H. Vinsons Synan, pp. 240-263, CPT, Cleveland, TN.

Zimmerman, T.F., 2012, 'The reason for the rise of the Pentecostal movement', in F. McClung (ed.), Azusa street and beyond: Missional commentary on the global Pentecostal/Charismatic movement, pp. 89-96, Bridge-Logos, Alachua, FL. 